\title{
Modeliranje procesa umreženja izolacije izoliranih vodiča energijskih kabela
}

\author{
V. Kosar, ${ }^{a^{*}}$ Z. Kraljevićb i M. Radovića \\ a Fakultet kemijskog inženjerstva i tehnologije, Sveučilište u Zagrebu, Marulićev trg 19, 10000 Zagreb \\ b Elka d. o. o, Koledovčina 1, 10000 Zagreb
}

\section{\| Sažetak}

Uobičajeno je da većina proizvođača u pogonu eksperimentalno određuje radne uvjete procesa umreženja i hlađenja proizvoda. Međutim, takav pristup ima manjkavosti prilikom proizvodnje novih proizvoda kada je potrebno predvidjeti nove radne uvjete. Isto tako, kada se upotrebljavaju drugi izolacijski materijali, potrebno je provesti niz nezavisnih eksperimenta za njihovu karakterizaciju. Sve to može dovesti do pogrešaka pri projektiranju nove opreme i proizvoda. S tim u svezi u ovom je radu predložen matematički model i provedena simulacija procesa kontinuiranog umreženja u vulkanizacijskoj cijevi.

U procesu proizvodnje energijskih izoliranih vodiča izolacija od umreživog polietilena nanosi se na vodič pri temperaturi nižoj od temperature umreženja. Vodič s nanijetim slojem polimera kontinuirano se vodi kroz vulkanizacijsku cijev pod tlakom dušika da bi se izolacija zagrijala na temperaturu raspada peroksidnog inicijatora odnosno temperaturu reakcije umreženja. Promjena radnih uvjeta u cijevi utječe na fizička svojstva izoliranih vodiča i posebno na njegova konačna primjenska svojstva. Značajke izolacijskog materijala s obzirom na brzinu umreženja određuju ukupni kapacitet linije odnosno brzinu prolaza izoliranog vodiča, pri čemu je često ograničavajući faktor kapacitet ekstrudera. Svrha ovoga rada bila je provjera primjenjivosti modela i programske podrške za različite proizvodne linije u tvornici kabela Elka d. o. o. Zagreb.

\author{
\| Ključne riječi \\ Umreženje, vulkanizacijska cijev, XLPE, izolirani vodiči, matematički model, simulacija
}

\section{Uvod}

Energijski kabel predstavlja skup vodiča, međusobno izoliranih kako ne bi došlo do neposrednog dodira sa zemljom ili drugim konstruktivnim elementima. Prema namjeni dijele se na prijenosnike električne energije i prijenosnike informacija. Pri prijenosu električne energije upotrebljavaju se nadzemni i podzemni kabeli. Za prijenos informacija upotrebljavaju se telekomunikacijski kabeli. Kabeli se polažu u zemlju, vodu i građevine. Izrađuju se za niske, srednje i visoke napone do 500 kV. Kabeli se u načelu sastoje od vodiča, izolacije, ekrana (električne zaštite), ispune, plašta i armature (slika 1).

Vodiči se izrađuju od bakra ili aluminija i služe za provođenje električne struje. Prema broju žica dijele se na jednožilne i višežilne vodiče. ${ }^{1}$ Danas se najčešće primjenjuje izolacija od umreženog polietilena niske gustoće (XLPE). U odnosu na tradicionalne polietilenske (PE) izolacije ovakva izolacija je toplinski postojanija, duljeg je životnog vijeka te ima izvanredna električna svojstva. Zbog dobre toplinske postojanosti takvi kabeli zovu se toplinski postojani električni kabeli. ${ }^{2,3}$ Da bi se poboljšala svojstva izolacije, upotrebljava se modificirani umreženi polietilen niske gustoće, XLPE. Modificirani XLPE za srednjenaponske izolacije sastoji se od polietilena niske gustoće (LDPE) i kopolimera etilena i etil-akrilat (EEAK). Osnovno svojstvo koje se dobiva tom modifikacijom je poboljšana preradljivost (ekstrudibilnost) i povećana otpornost na degradaciju izolacije pod djelovanjem električne struje u prisutnosti vlage. ${ }^{4,5}$

*Autor za dopisivanje: Izv. prof. dr. sc. Vanja Kosar e-pošta: vkosar@fkit.hr

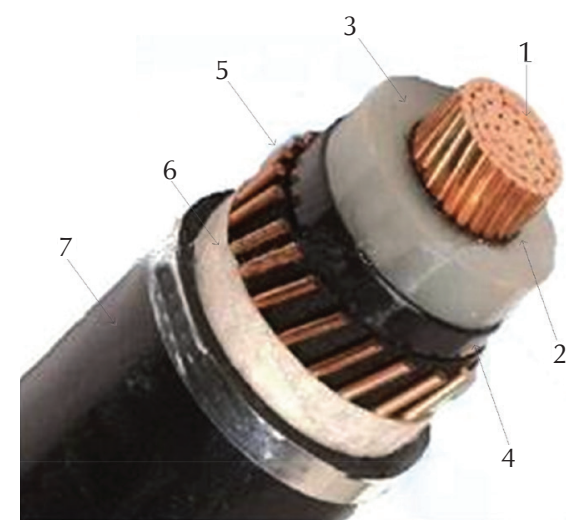

Slika 1 - Opći prikaz presjeka kabela (1 - vodič; 2 - unutarnji poluvodljivi sloj; 3 - izolacija; 4 - vanjski poluvodljivi sloj; 5 - električna zaštita; 6 - separator; 7 - vanjski plašt)

Fig. 1 -Cable cross-section (1 - conductor; 2 - conductor screen; 3 - insulation; 4 - insulation screen; 5 - electric protection/screen; 6 - swelling tape; 7 - external sheath)

\section{Proces proizvodnje energijskih kabela}

Linija za proizvodnju radi kontinuirano. Vodič, koji je namotan na odmotač, prije ulaska u ekstruder predgrijava se do maksimalno $130{ }^{\circ} \mathrm{C}$. Postupak izoliranja vodiča započinje troslojnom ekstruzijom u ekstruderu u koji ulaze predgrijani vodič te poluvodički i izolatorski materijali. U 
ekstruderu dolazi do oblaganja vodiča poluvodičkim slojem (vanjskim i unutarnjim) i slojem izolacije u troslojnom procesu ekstruzije. Nakon toga izolirani vodič ulazi u vulkanizacijsku cijev (slika 2), gdje se u inertnoj atmosferi dušika i pri povišenoj temperaturi provodi proces vulkanizacije, tj. umreženja izolacijskog materijala. Sama vulkanizacijska cijev podijeljena je na sedam grijanih zona. Svaka od zona održava se na drugoj temperaturi. Kod proizvodnje srednjenaponskih kabela prva zona je na najvišoj temperaturi, dok u ostalim zonama temperatura opada. Kod visokonaponskih kabela situacija je malo drugačija, tj. kroz zone temperatura raste, a razlog tome je ovješenje kabela zbog velike debljine izolacije, odnosno velike mase kabela. Sukladno tome proces se vodi pri nižim brzinama i temperaturama da bi proces umreženja i poslije hlađenja bio postupan. Duljina svake zone je 5,5 m. Nakon vulkanizacije izolirani vodič se hladi u dva stupnja. Prvi stupanj je vodeno hlađenje (moguće je i hlađenje dušikom da se smanji mogućnost apsorpcije vode u izolaciji kod visokonaponskih kabela), a drugi stupanj je hlađenje zrakom. Protok vode u vodenom dijelu hlađenja je oko $15 \mathrm{~m}^{3} \mathrm{~h}^{-1}$, a duljina cijevi je $76 \mathrm{~m}$. Duljina linije hlađene zrakom (od izlaza iz vodenog dijela do koluta za namatanje) je $118 \mathrm{~m}$. Nakon hlađenja temperatura izoliranog vodiča je oko $45{ }^{\circ} \mathrm{C}$ te se kao takav može namotati i skladištiti.

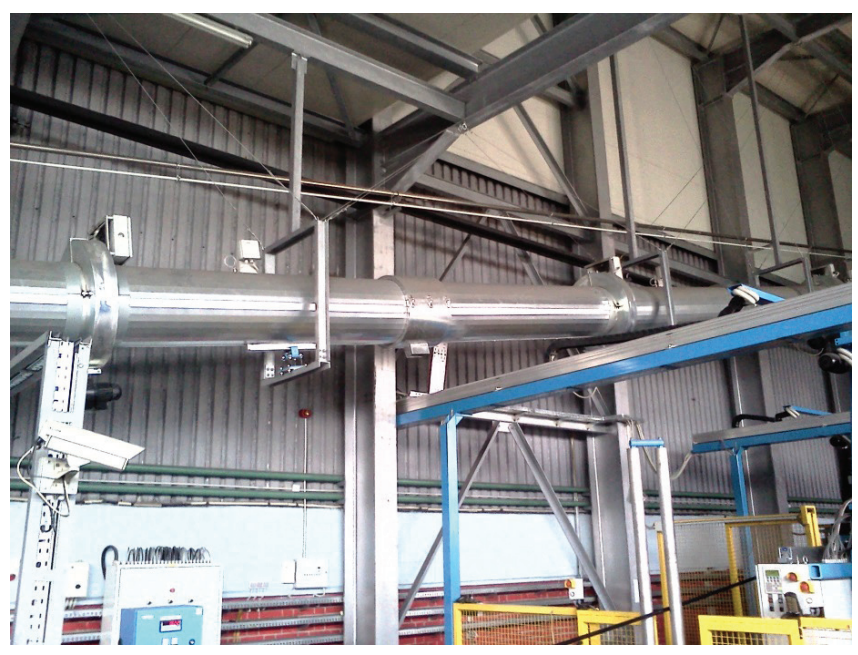

Slika 2 - Vulkanizacijska cijev

Fig. 2 - Vulcanization tube

\section{Modeliranje i optimiranje proizvodnog procesa}

U postojećoj proizvodnji izoliranih vodiča mogućnosti za smanjenje troškova i povećanje ekonomičnosti proizvodnje nalaze se u optimiranju procesnih parametara, od kojih su najvažniji: kapacitet ekstrudera, brzina linije, temperatura po zonama, protok i temperatura rashladne vode. ${ }^{6}$ Ti parametri međusobno su zavisni, te je kroz simulaciju procesa potrebno ustanoviti optimalne vrijednosti. S obzirom na to da je sadašnja linija za kontinuiranu vulkanizaciju izoliranih vodiča (KV-6) u tvrtki Elka d. o. o. pokrenuta prije pet godine, neki od tih parametara su poboljšani u odnosu na staru liniju (KV-4, koja je u upotrebi 30-ak godina). Važan tehnološki parametar je maksimalna brzina linije pri kojoj će se dobiti proizvod dobre kvalitete. Brzina linije ima dvojak utjecaj na proces. S obzirom na reakciju umreženja veća brzina linije znači kraće vrijeme zadržavanja i manji stupanj umreženja po presjeku izolacije. Međutim, veća brzina linije pospješuje hlađenje izoliranog vodiča i proizvodnju veće količine proizvoda u istom vremenu. $U$ dosadašnjem radu za srednjenaponski 20 kV kabel presjeka $150 \mathrm{~mm}^{2}$ na KV-4 optimalna brzina linije mogla je biti oko $8 \mathrm{~m} \mathrm{~min}^{-1}$, dok KV-6 radi s brzinom od oko $15 \mathrm{~m} \mathrm{~min}^{-1}$. Temperatura dušika u zonama grijanja vulkanizacijske cijevi utječe na brzinu reakcije umreženja. Simulacijom se može predvidjeti optimalna temperatura za svaku zonu s obzirom na proizvod koji se provodi za potreban stupanj umreženja. Temperatura i protok vode odgovorni su za hlađenje izoliranog vodiča. Za hlađenje se upotrebljava procesna voda čija je temperatura regulirana na ulazu i izlazu iz cijevi za hlađenje. Protok iznosi oko $15 \mathrm{~m}^{3} \mathrm{~h}^{-1}$, što je znatno više od protoka koji je bio na KV-4 (oko $3 \mathrm{~m}^{3} \mathrm{~h}^{-1}$ ). ${ }^{4}$

Vulkanizacijska cijev (slika 2) može se smatrati cijevnim reaktorom u kojem je reakcijska smjesa izolacija kabela i za koji se pri izvođenju modela mogu uzeti u obzir sljedeće pretpostavke: ${ }^{6}$

1. stacionarnost rada

2. prolazak izoliranog vodiča može se opisati modelom idealnog strujanja

3. reakcija se odvija unutar polimera koji je nanijet na metalnu jezgru

4. toplina se prenosi s unutarnje stijenke vulkanizacijske cijevi kroz plinoviti dušik do vanjske površine PE izolacije i zatim kroz masu

5. prijenos topline postoji samo u radijalnom smjeru s unutarnje stijenke vulkanizacijske cijevi zagrijane na visoku temperaturu do površine izolatora čija je ulazna temperatura na izlazu iz ekstrudera oko $280{ }^{\circ} \mathrm{C}$

6. brzina umreženja, a time i stupanj umreženja te temperatura unutar izoliranog vodiča funkcije su prostornih koordinata u aksijalnom i radijalnom smjeru

7. pretpostavlja se postojanje graničnog, laminarnog sloja dušika oko izoliranog vodiča kroz koji se toplina prenosi difuzijom

8. pretpostavlja se stalna temperatura dušika u cijevi koja je jednaka onoj stijenke vulkanizacijske cijevi zbog stacionarnog načina rada

9. postoji jedinstveni koeficijent prijenosa topline koji uključuje i konvektivni i radijacijski prijenos.

Tri se područja unutar vulkanizacijske cijevi odvojeno razmatraju pri izvođenju modela: ${ }^{5}$

Dušik pod tlakom, plinska faza. Njegova je temperatura jednaka onoj unutarnje stijenke vulkanizacijske cijevi koja je grijana električnim otporničkim grijačima. 
Sloj polimera koji se nanosi na vodič pri ulazu u cijev i koji je zagrijan na početnu temperaturu $\left(280^{\circ} \mathrm{C}\right)$. Do površine toplina se prenosi radijacijom i konvekcijom kroz dušik sa zagrijane stijenke vulkanizacijske cijevi. Unutar polimera odvija se slabo egzotermna reakcija umrežavanja.

Jezgra izoliranog vodiča je kompaktirani metalni vodič (Al, $\mathrm{Cu}$ i i toplina se kroz jezgru prenosi isključivo provođenjem u aksijalnom i radijalnom smjeru.

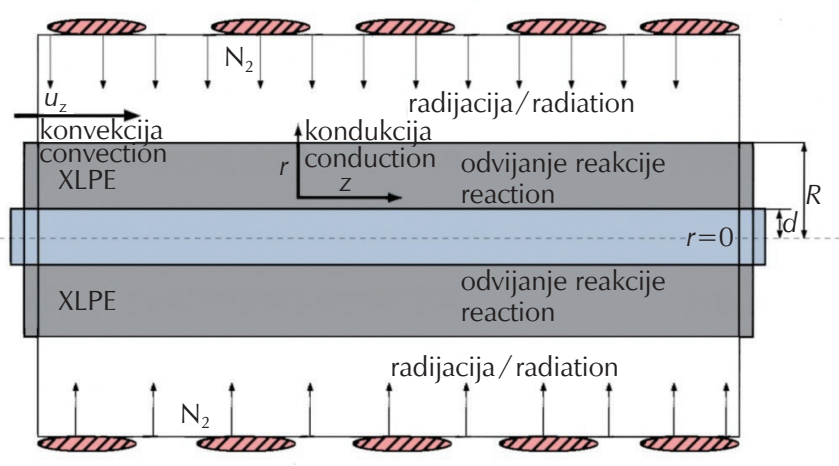

Slika 3 - Prijenos topline u vulkanizacijskoj cijevi Fig. 3 - Heat transfer in the vulcanization tube

Model je predočen s bilančnim jednadžbama:

- Bilanca tvari u polimeru (reakcija u cijevnom reaktoru)

$$
u \rho_{\mathrm{p}} \frac{\partial P}{\partial z}-r_{\mathrm{p}}=0
$$

- Kinetički model reakcije umrežavanja polimera ${ }^{7}$

$$
r_{\mathrm{p}}=A_{\mathrm{r}} \mathrm{e}^{\frac{-E_{\mathrm{a}}}{R_{\mathrm{g}} T}} P^{n}(1-P)^{m}
$$

- Bilanca topline za polimer

$$
u \rho_{p} c_{p p} \frac{\partial T}{\partial z}-\lambda_{p}\left[\frac{\partial^{2} T}{\partial r^{2}}+\frac{1}{r} \frac{\partial T}{\partial r}\right]+\left(-\Delta H_{r}\right) r_{p}=0
$$

- Bilanca topline za vodič

$$
u \rho_{\mathrm{j}} C_{p j} \frac{\partial T}{\partial z}-\lambda_{\mathrm{j}}\left[\frac{\partial^{2} T}{\partial r^{2}}+\frac{1}{r} \frac{\partial T}{\partial r}\right]=0
$$

Za predloženi model koji predstavlja sustav parcijalnih diferencijalnih jednadžbi (PDJ) potrebno je definirati ulazne i rubne uvjete. ${ }^{8,9}$

- Uvjeti na ulazu u cijev, $z=0$

$$
P(0, R-d)=0
$$

$$
\begin{gathered}
T_{\mathrm{j}}(0, d)=T_{\mathrm{j}}^{0} \\
T_{\mathrm{p}}(0, R-d)=T_{\mathrm{p}}^{0}
\end{gathered}
$$

- Rubni uvjeti na površini izolacije i granici polimer - vodič

$r=R$, površina izolacije za sve $z$

$$
h\left(T_{z, R}-T_{N}\right)+Q_{\mathrm{rad}}=-\lambda_{\mathrm{p}} \frac{\partial T}{\partial r}
$$

$r=d$, granica polimer - vodič za sve $z$

$$
\lambda_{\mathrm{p}} \frac{\partial T_{\mathrm{p}}}{\partial r}=\lambda_{\mathrm{j}} \frac{\partial T_{\mathrm{j}}}{\partial r}
$$

$r=0$, centar simetrije

$$
\frac{\partial T_{j}}{\partial r}=0
$$

- Prijenos topline radijacijom

$$
Q_{\text {rad }}=\frac{\delta\left(T_{1}^{2}+T_{2}^{2}\right)\left(T_{1}+T_{2}\right)}{\frac{1}{\varepsilon_{1}}+\frac{A_{1}}{A_{2}}\left(\frac{1}{\varepsilon_{2}}-1\right)}
$$

Na osnovi pretpostavke o jedinstvenom koeficijentu prijenosa rubni uvjet na površini izolacije je tada u bezdimenzijskom obliku:

$$
\frac{\partial \theta}{\partial r}=\frac{\left(h+h_{r}\right) R}{\lambda_{\mathrm{p}}}\left(1-\theta_{N}\right)
$$

Stoga se jednadžba (8) zamjenjuje jednadžbom (12), pri čemu indeks $N$ u obje jednadžbe ukazuje na temperaturu dušika u neposrednoj blizini vulkanizacijske cijevi.

\section{Simulacija procesa}

U ovom dijelu rada prikazat će se mogućnosti programskih rješenja za obje proizvodne linije KV-4 i KV-6. Program napisan za optimiranje linije KV-4 bit će testiran na "novijoj" liniji KV-6. Uspoređujući procijenjene temperature na površini izolacije po "zonama" (slika 4) dobivene simulacijskim programom nabavljenim u sklopu linije KV-6 između pojedinih proizvoda, uočava se suštinska razlika između srednjenaponskih i visokonaponskih kabela. Kod srednjenaponskih kabela, uslijed veće brzine linije i viših temperatura na grijačima, po zonama temperature se smanjuju od početka do kraja linije. Kod visokonaponskih kabela je suprotan slučaj. Zbog velike "debljine" izolacije za postizanje potpunog umreženja potrebno je dulje vrijeme zadržavanja u cijevi, što se postiže malom brzinom linije i nižom temperaturom po zonama, pri čemu se osigurava ravnomjerno umreženje i hlađenje. 


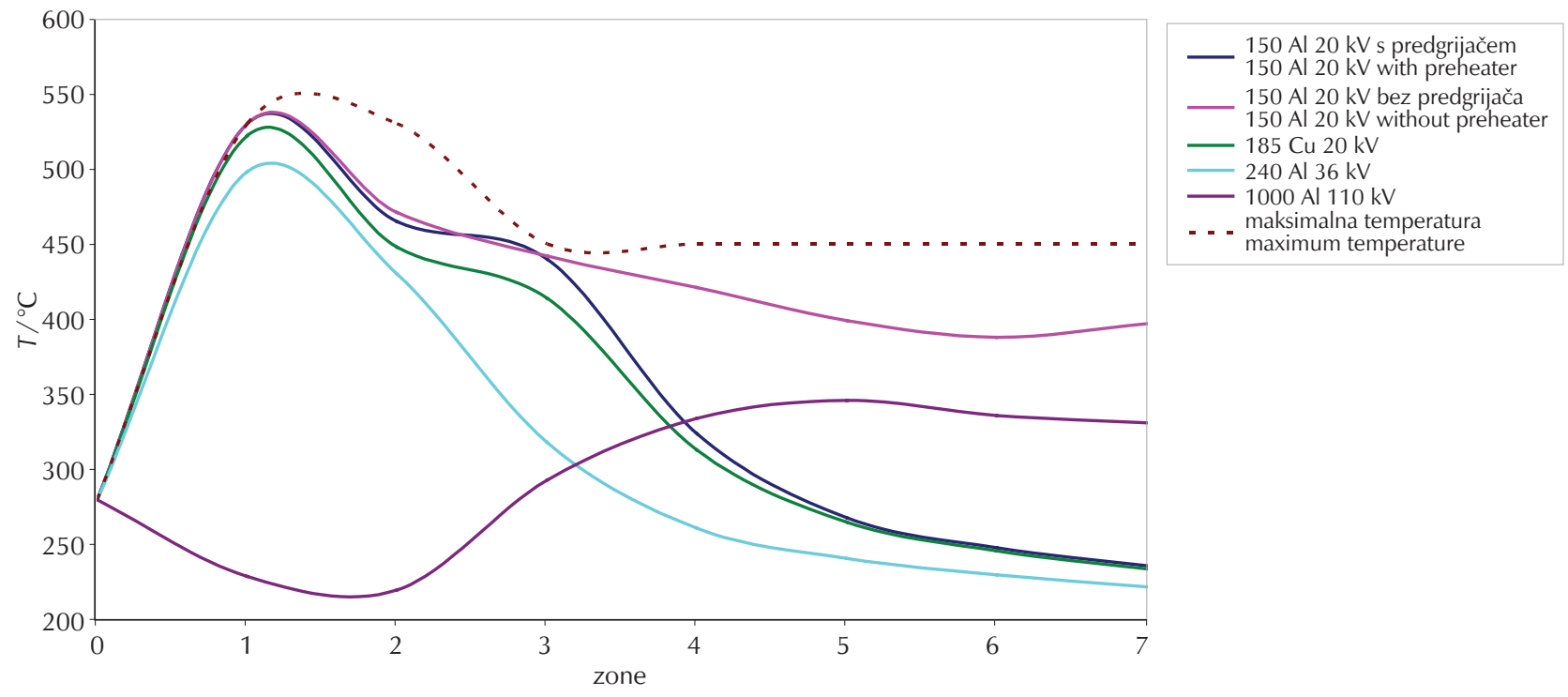

Slika 4 - Procijenjene temperature po zonama vulkanizacijske cijevi

Fig. 4 - Calculated temperature profile along the vulcanization tube

U sljedećim tablicama (tablice 1 i 2) prikazani su podatci i konstante važne za simulacijski program.

Tablica 1 - Fizičke konstante u sustavu na $100{ }^{\circ} \mathrm{C}$

Table 1 - Physical properties for the used material at $100{ }^{\circ} \mathrm{C}$

\begin{tabular}{l|c|c|c}
\hline $\begin{array}{l}\text { Materijal } \\
\text { Material }\end{array}$ & $\rho / \mathrm{kg} \mathrm{m}^{-3}$ & $C_{\mathrm{p}} / \mathrm{J} \mathrm{kg}^{-1} \mathrm{~K}^{-1}$ & $\lambda / \mathrm{W} \mathrm{m}^{-1} \mathrm{~K}^{-1}$ \\
\hline $\begin{array}{l}\text { vodič, } \mathrm{Al} \\
\text { conductor, Al }\end{array}$ & 2707 & 896 & 206 \\
$\begin{array}{l}\text { izolacija, XLPE } \\
\text { insulation, XLPE }\end{array}$ & 922 & 2700 & 0,335 \\
$\begin{array}{l}\text { dušik, } \mathrm{N}_{2} \\
\text { nitrogen, } \mathrm{N}_{2}\end{array}$ & 8,53 & 1045 & 0,03335 \\
$\begin{array}{l}\text { voda, } \mathrm{H}_{2} \mathrm{O} \\
\text { water, } \mathrm{H}_{2} \mathrm{O}\end{array}$ & 963 & 4200 & 0,665 \\
\hline
\end{tabular}

U nastavku ovoga rada bit će prezentirane simulacije napravljene uz pomoć već postojećeg računalnog proračuna, izvedenog kako bi se opisala starija linija na pogonu KV-4. Za razliku od linije KV-6, čiji je sastavni dio i simulacijski paket kupljen od dobavljača, KV-4 nije imao takvu podršku pa je stoga bilo vrlo važno za provjeru imati program. $U$ proračunu se primjenjuje model autokatalitičke reakcije (jedn. 2) i vulkanizacijska cijev dijeli na šest dijelova od kojih je svaki duljine 6 m (36 m dugačka vulkanizacijska cijev). U stvarnosti KV-6 dijeli vulkanizacijsku cijev na sedam dijelova dugačkih 5,5 m (ukupno 38,5 m). Međutim, bez obzira na te razlike, rezultati simulacija pokazuju cjelokupno i brzo umreženje izolacijskog materijala uzimajući u obzir da je ukupna duljina za proračun kraća 2,5 m i da postoji jedna zona vulkanizacije manje (slike 4 i 6 , tablica 2).
Tablica 2 - Zadani procesni podatci za proračun

Table 2 - Process parameters for the cable production line

\begin{tabular}{|c|c|c|c|c|c|}
\hline $\begin{array}{l}\text { Presjek vodiča } / \mathrm{mm}^{2} \\
\text { Conductor } \\
\text { cross-section } / \mathrm{mm}^{2}\end{array}$ & 150 & 185 & 240 & 800 & 1000 \\
\hline $\begin{array}{l}\text { Nazivni napon / kV } \\
\text { Nominal voltage / kV }\end{array}$ & 20 & 20 & 36 & 110 & 110 \\
\hline $\begin{array}{l}R \text { (izolirani vodič) } / \mathrm{mm} \\
R \text { (insulated conductor }) / \mathrm{mm}\end{array}$ & 13,6 & 14,4 & 22,3 & 35,9 & 36,8 \\
\hline $\begin{array}{l}d(\text { vodič }) / \mathrm{mm} \\
d(\text { conductor }) / \mathrm{mm}\end{array}$ & 7,05 & 7,85 & 9 & 18,45 & 19,6 \\
\hline $\begin{array}{l}\text { Brzina linije } / \mathrm{m} \mathrm{min}^{-1} \\
\text { Line speed } / \mathrm{m} \mathrm{min}^{-1}\end{array}$ & 15,89 & 13,68 & 8,93 & 6,80 & 1,49 \\
\hline$T_{1} /{ }^{\circ} \mathrm{C}$ & 530 & 522 & 498 & 510 & 229 \\
\hline $\mathrm{T}_{2} /{ }^{\circ} \mathrm{C}$ & 471 & 448 & 430 & 450 & 220 \\
\hline$T_{3} /{ }^{\circ} \mathrm{C}$ & 443 & 414 & 318 & 425 & 293 \\
\hline$T_{4} /{ }^{\circ} \mathrm{C}$ & 421 & 313 & 261 & 410 & 334 \\
\hline$T_{5} /{ }^{\circ} \mathrm{C}$ & 399 & 265 & 241 & 402 & 346 \\
\hline$T_{6} /{ }^{\circ} \mathrm{C}$ & 388 & 246 & 230 & 390 & 336 \\
\hline
\end{tabular}

Računalnim programom moguće je prikazati neke funkcijske ovisnosti promatranih veličina (temperature i stupnja umreženja) o duljini $(L)$ i polumjeru $(R)$ izoliranog vodiča i cijevi. U nastavku će biti prikazane funkcijske ovisnosti za sljedeća dva proizvoda iz gornje tablice: srednjenaponski kabel presjeka $240 \mathrm{~mm}^{2}$ i visokonaponski kabel presjeka $800 \mathrm{~mm}^{2}$. Prikazat će se sljedeće:

a) promjena stupnja umreženja polimera po dužini vulkanizacijske cijevi za određene polumjere 
b) promjena temperature kabela po dužini vulkanizacijske cijevi za određene polumjere

c) promjena stupnja umreženja polimera po presjeku za određene položaje u vulkanizacijskoj cijevi.

Simulacije bi trebale pokazati da na kraju vulkanizacijske cijevi po presjeku izolacije dolazi do stupnja umreženja $90 \%$. Može se uočiti da za izolirani vodič presjeka $240 \mathrm{~mm}^{2}$ ne dolazi do potpunog umreženja u masi polimera (slika 5), dok kod izoliranog vodiča presjeka 800 mm² dolazi (slika 6). To se može objasniti i razlikom u brzini linije. Naime, izolirani vodiči manjeg presjeka imaju veću brzinu prolaska te samim time i manje vrijeme zadržavanja u pojedinom dijelu i "nedovoljno" vrijeme za jednoliko umrežavanje izolacije od vodiča do površine. Posebno je problematičan sloj izolacije neposredno uz vodič. Mogućnost predgrijavanja vodiča (KV-6, do $\left.130{ }^{\circ} \mathrm{C}\right)$ rješava taj problem.

Na svim slikama prati se ovisnost promjene konverzije i temperature za određene polumjere izoliranog vodiča odnosno položaje po poprečnom presjeku. Treba naglasiti

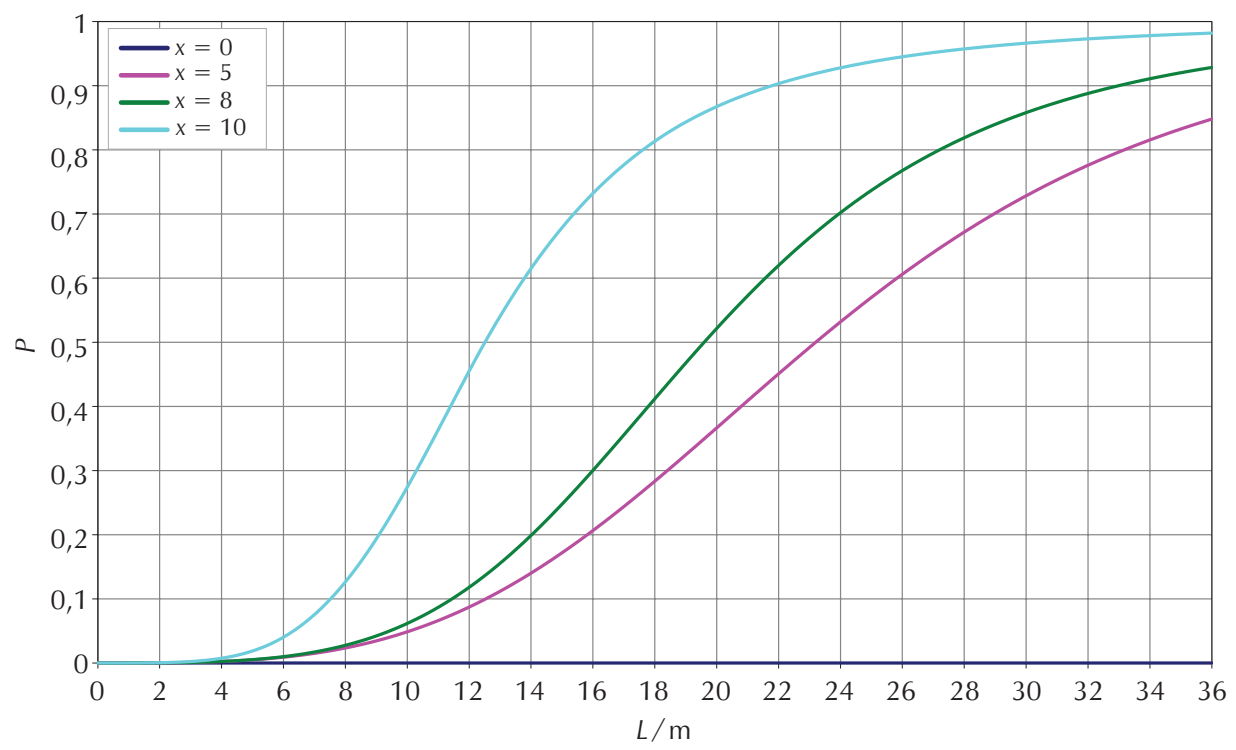

Slika 5 - Ovisnost stupnja umreženja polimera o položaju u vulkanizacijskoj cijevi za izolirani vodič presjeka $240 \mathrm{~mm}^{2}$

Fig. 5 - Calculated degree of crosslinking profiles along the vulcanization tube for insulated conductor cross-section $240 \mathrm{~mm}^{2}$

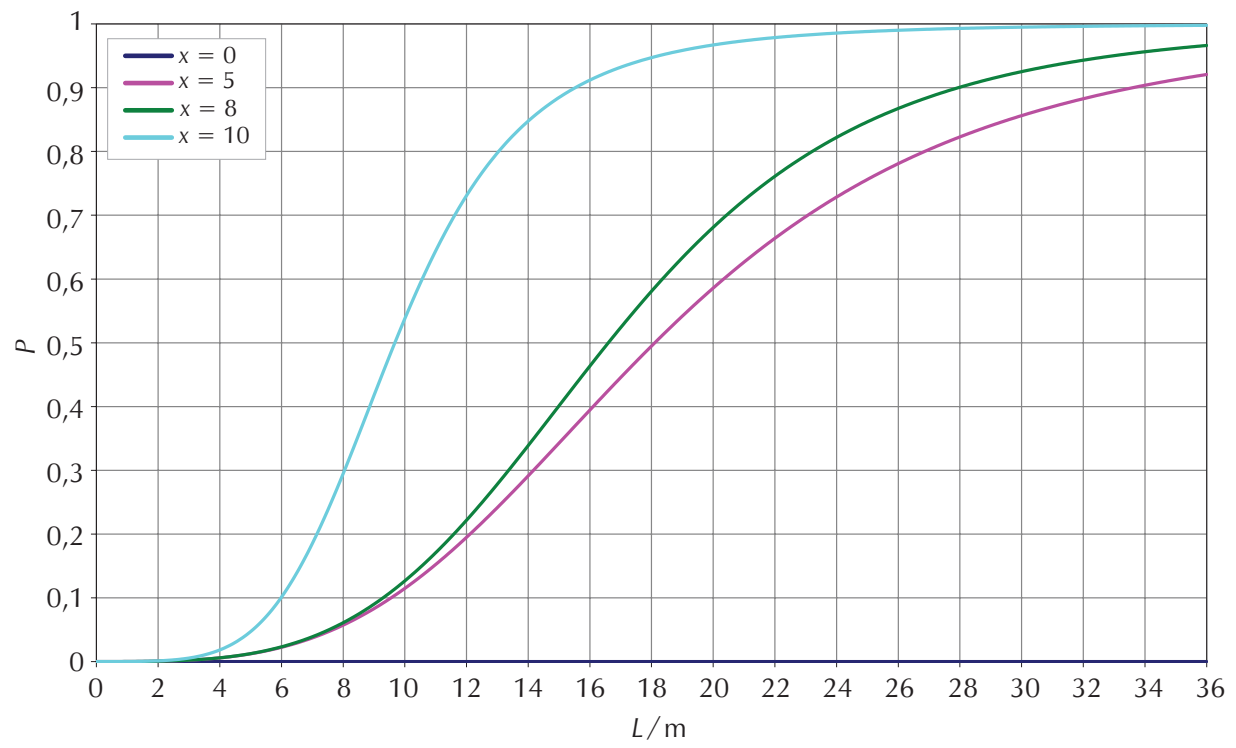

Slika 6 - Ovisnost stupnja umreženja polimera o položaju u vulkanizacijskoj cijevi za izolirani vodič presjeka $800 \mathrm{~mm}^{2}$

Fig. 6 - Calculated degree of crosslinking profiles along the vulcanization tube for insulated conductor cross-section $800 \mathrm{~mm}^{2}$ 
da se radi o bezdimenzijskim polumjerima. Prilikom računanja izolirani vodič podijeljen je po presjeku na deset jednakih dijelova, četiri za vodič i šest za polimernu izolaciju. Oznake u legendama na slikama upućuju na položaje kako slijedi:

1. $x=0$, središte, aluminijski vodič u kojem ne dolazi do kemijske reakcije

2. $x=5$, prvi sloj polimera uz vodič

3. $x=8$, približno sredina izolacije

4. $x=10$, površina izolacije
Na osnovi matematičkog modela procesa simulirani su profili temperatura po dužini kabela za određene bezdimenzijske polumjere unutar izolacije kabela. Na slikama 7 i 8 vidi se da temperatura kroz vulkanizacijsku cijev raste od ulaza do izlaza. Očekivano veće temperature na izlazu izračunate su za izolirani vodič presjeka $800 \mathrm{~mm}^{2}$. Potrebno je naglasiti da proizvodni proces teče dalje hlađenjem proizvoda u dva stupnja. Proces hlađenja također se može simulirati modelom što je prikazano u prethodnim radovima $^{4,5}$

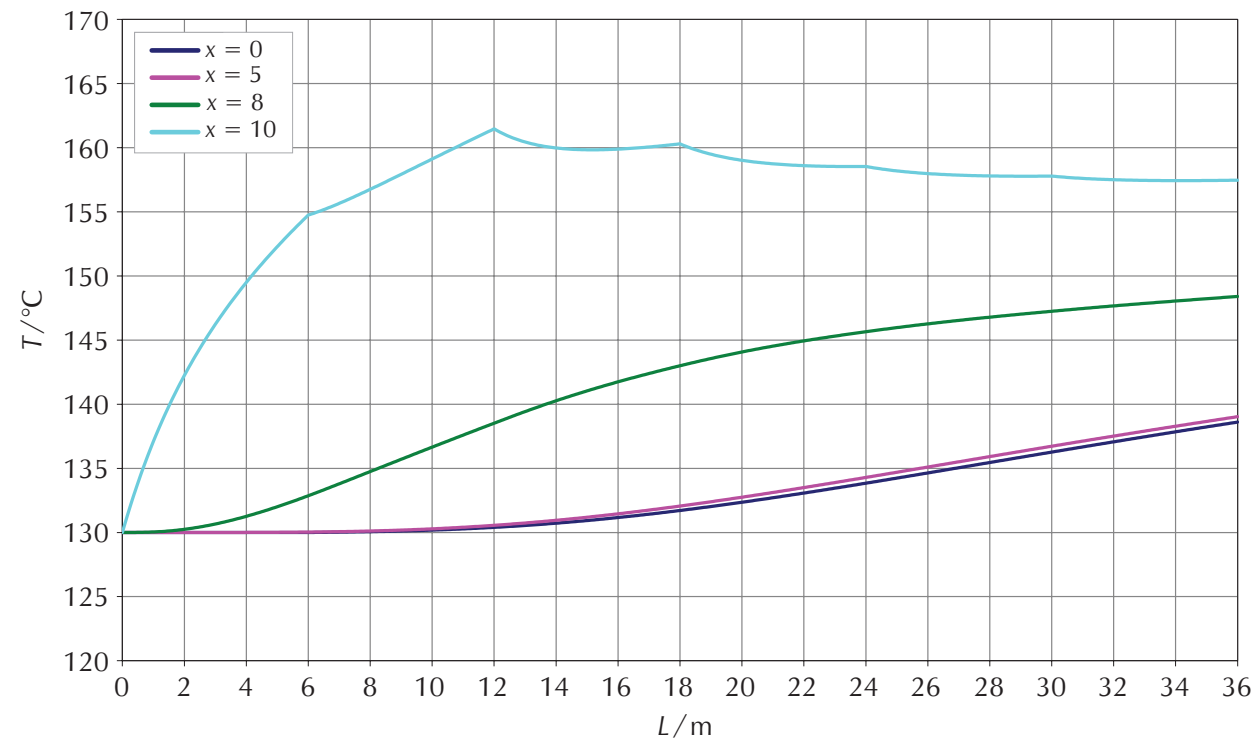

Slika 7 - Ovisnost temperature kabela za određeni bezdimenzijski polumjer o dužini vulkanizacijske cijevi za izolirani vodič presjeka $240 \mathrm{~mm}^{2}$

Fig. 7 - Calculated temperature profiles along the vulcanization tube at different dimensionless radial positions for insulated conductor cross-section $240 \mathrm{~mm}^{2}$

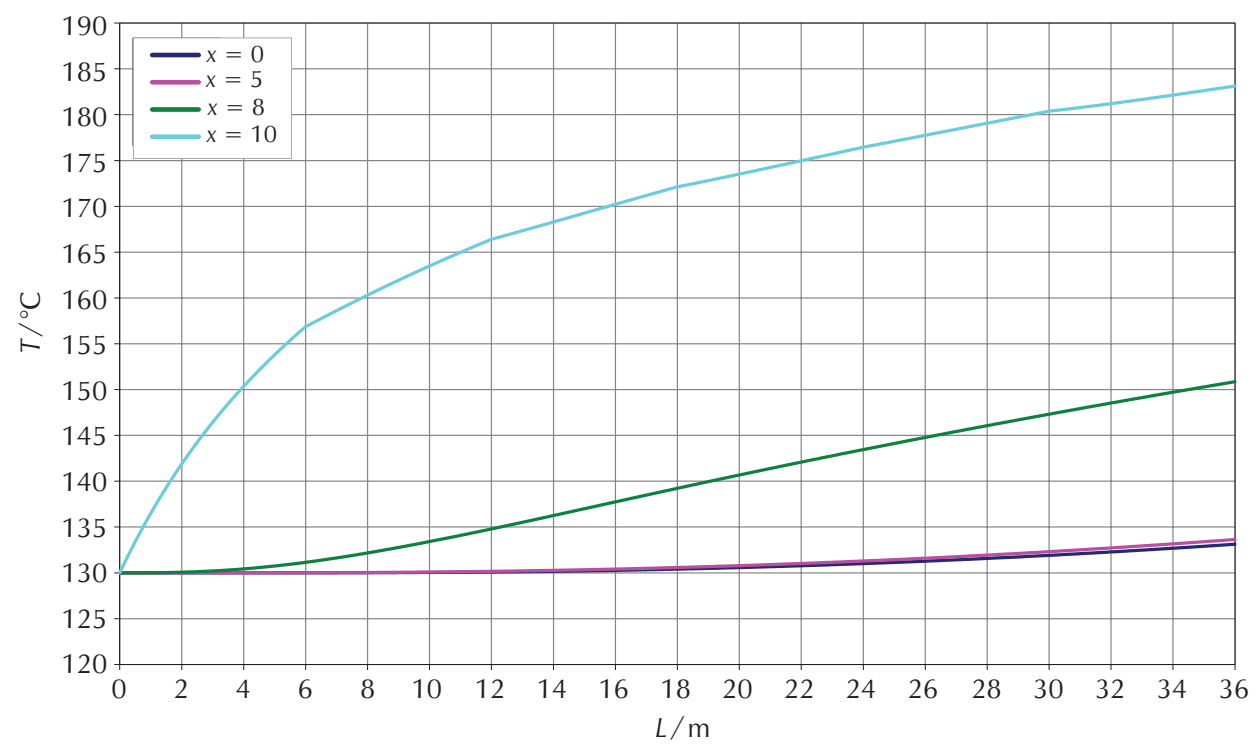

Slika 8 - Ovisnost temperature kabela za određeni bezdimenzijski polumjer o dužini vulkanizacijske cijevi za izolirani vodič presjeka vodiča $800 \mathrm{~mm}^{2}$

Fig. 8 - Calculated temperature profiles along the vulcanization tube at different dimensionless radial positions for insulated conductor cross-section $800 \mathrm{~mm}^{2}$ 


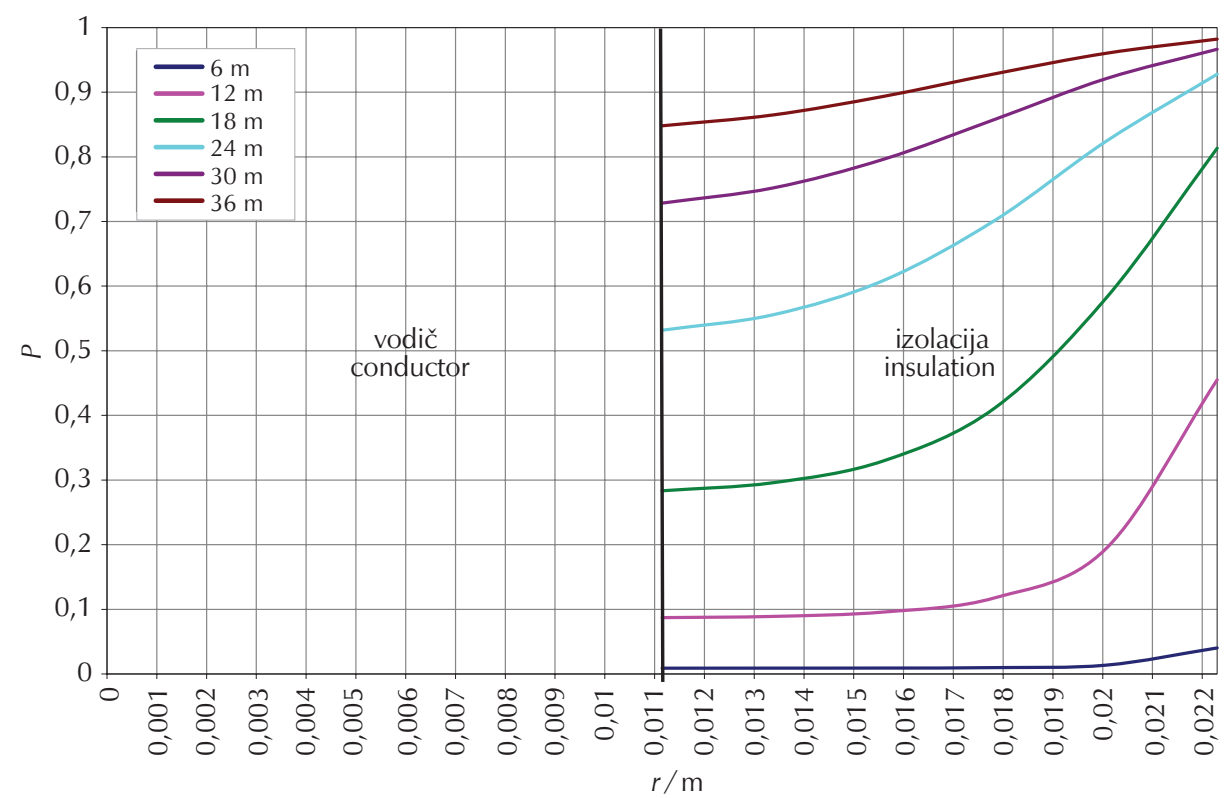

Slika 9 - Ovisnost stupnja umreženja o polumjeru na određenoj udaljenosti za izolirani vodič presjeka $240 \mathrm{~mm}^{2}$

Fig. 9 - Calculated radial degree of crosslinking profiles through the cable at different positions in the tube for insulated conductor cross-section $240 \mathrm{~mm}^{2}$

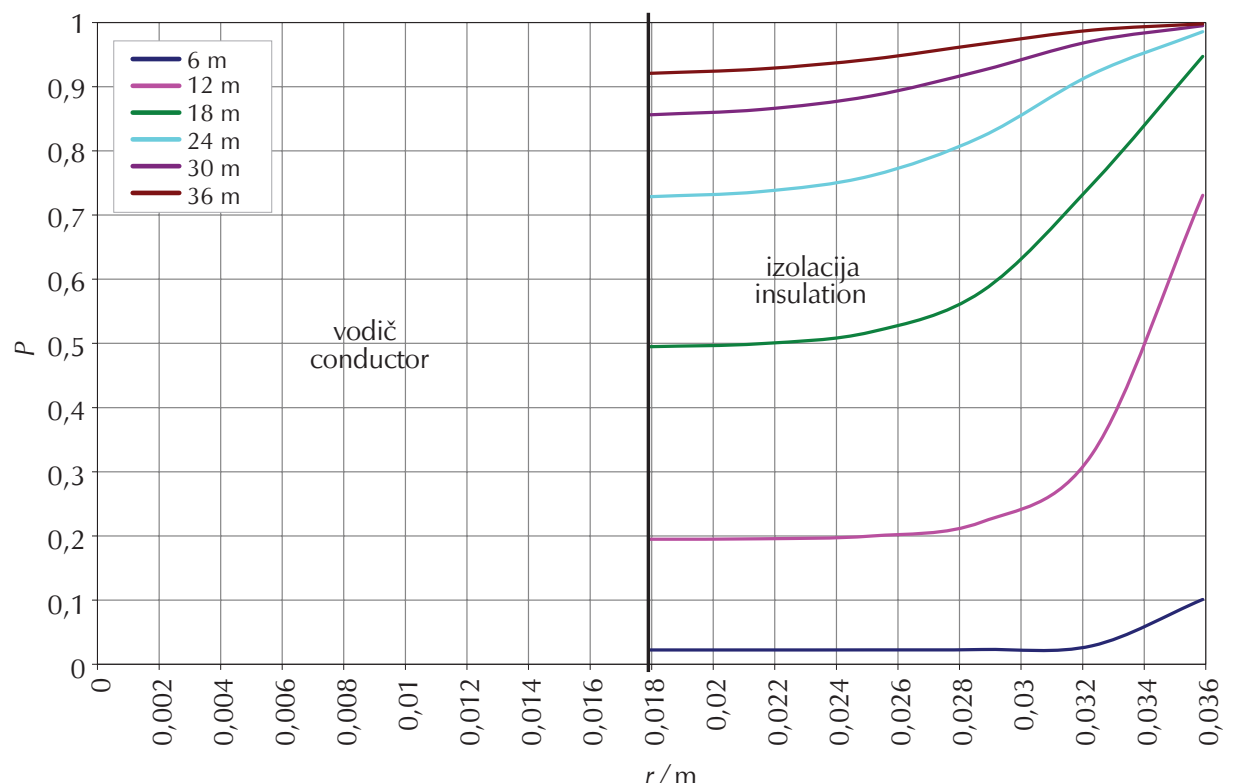

Slika 10 - Ovisnost stupnja umreženja o polumjeru na određenoj udaljenosti za izolirani vodič presjeka $800 \mathrm{~mm}^{2}$

Fig. 10 - Calculated radial degree of crosslinking profiles through the cable at different positions in the tube for insulated conductor cross-section $800 \mathrm{~mm}^{2}$

Zbog male toplinske vodljivosti polimera toplina se sporo provodi od površine prema jezgri. Samim time, stupanj umreženja polimera je najmanji neposredno uz površinu vodiča. U šestom segmentu $(30-36$ m) dolazi do ujednačavanja konverzija po cijelom presjeku izolacije. Kao i kod prethodnih rezultata (slike 5 i 6), s obzirom na kraće vrijeme zadržavanja uslijed veće brzine prolaza, postiže se manji stupanj umreženja po presjeku izolacije kod izoliranog vodiča presjeka $240 \mathrm{~mm}^{2}$ u odnosu na $800 \mathrm{~mm}^{2}$.

Na kraju treba reći da prikazana istraživanja (model vulkanizacijske cijevi, simulacije) predstavljaju manji dio opisa cjelovitog procesa proizvodnje energijskih kabela u tvornici Elka d. o. o. Jednako važna su i prethodna ispitivanja ulaznih materijala, vodiča i izolacije, ${ }^{10}$ nanošenje izolacije na vodič (izvedba ekstrudera, kapacitet), hlađenje, otplinjavanje kabela u komorama (nužno kod visokonaponskih kabela zbog zaostajanja plinova u izolaciji) te ostala standardizirana tipska ispitivanja proizvoda. Isto tako, s obzirom na to da se radi o kontinuiranoj proizvodnji, potrebno je riješiti problem pregrijavanja uslijed smanjenja brzine linije (u nekim slučajevima s $20 \mathrm{~m} \mathrm{~min}^{-1}$ na $8 \mathrm{~m} \mathrm{~min}^{-1}$ pri spajanju vodiča) za nesmetani nastavak rada. 


\section{Zaključak}

U radu je provedena simulacija procesa umreženja izolacije i prijenosa topline na osnovi predloženog matematičkog modela i dostupnih podataka za radne uvjete proizvodnje izoliranih vodiča poprečnih presjeka 240 i $800 \mathrm{~mm}^{2}$. Na osnovi provedenih simulacija i rasprave može se zaključiti:

- Predložen je matematički model procesa i provedena simulacija za trenutačne radne uvjete na pogonu KV-6.

- U svrhu provjere i simulacije modela primijenjeno je odgovarajuće programsko rješenje za numeričko rješavanje skupa PDJ, kojim su opisane odgovarajuće bilance. Također, postupak procjene pojedinih parametara ugrađen je u programsko rješenje.

- Provedene su simulacije za izolirane vodiče koji se proizvode na pogonu KV-6 kao "sirovine" za srednjenaponski kabel nazivnog napona $36 \mathrm{kV}$ s vodičem od aluminija poprečnog presjeka $240 \mathrm{~mm}^{2}$ te visokonaponski kabel nazivnog napona $110 \mathrm{kV}$ s vodičem od aluminija poprečnog presjeka $800 \mathrm{~mm}^{2}$. Oba proizvoda imaju izolaciju od umreženog polietilena. Simulacije pokazuju dobar odabir procesnih parametara (tablica 2).

- Od svih procesnih parametara najveći utjecaj na konačni stupanj umreženja ima brzina linije o kojoj ovisi vrijeme zadržavanja kao i hlađenje izoliranog vodiča u vodi i na zraku.

- Prikazan matematički model simulira procesne uvjete prilikom proizvodnje na liniji KV-6 pogonu tvrtke Elka d. o. o. Iz simulacija se vidi da se linija KV-6 može također dobro opisati predloženim matematičkim modelom prethodno izrađenim za liniju KV-4., ${ }^{4,5}$

\section{Popis kratica i simbola \\ List of abbreviations and symbols}

XLPE- umreženi polietilen

- cross-linked polyethylene

A - površina prijenosa topline, $\mathrm{m}^{2}$

- area of heat exchange, $\mathrm{m}^{2}$

$A_{\mathrm{r}} \quad$ - Arrheniusov predeksponencijalni faktor, $\mathrm{s}^{-1}$

- Arrhenius pre-exponential factor, $\mathrm{s}^{-1}$

$c_{\mathrm{p}} \quad$ - specifični toplinski kapacitet, $\mathrm{J} \mathrm{kg}^{-1} \mathrm{~K}^{-1}$

- specific heat capacity, $\mathrm{J} \mathrm{kg}^{-1} \mathrm{~K}^{-1}$
D - polumjer vodiča, $\mathrm{m}$

- core diameter, $\mathrm{m}$

$E_{\mathrm{a}} \quad$ - aktivacijska energija, $\mathrm{J} \mathrm{mol}^{-1}$

- activation energy, J $\mathrm{mol}^{-1}$

$\Delta H_{\mathrm{r}}$ - reakcijska entalpija, $\mathrm{Jg}^{-1}$

- heat of reaction, $\mathrm{Jg}^{-1}$

$h \quad$ - koeficijent prijenosa topline, $\mathrm{J} \mathrm{s}^{-1} \mathrm{~m}^{-2} \mathrm{~K}^{-1}$

- heat transfer coefficient, $\mathrm{J} \mathrm{s}^{-1} \mathrm{~m}^{-2} \mathrm{~K}^{-1}$

- vodič

- conductor

$k \quad-$ konstanta brzine reakcije, $\mathrm{s}^{-1}$

- rate constant, $\mathrm{s}^{-1}$

L $\quad$ - dužina kabela, cijevi, m

- cable length, $\mathrm{m}$

$m, n$ - parametri kinetičkog modela

- kinetic constants

$P \quad$ - stupanj umreženja

- degree of cross-linking

p - polimer (izolacija)

- insulation

Q - toplinski tok, $\mathrm{J} \mathrm{s}^{-1} \mathrm{~K}^{-1}$

- heat flux, $\mathrm{J} \mathrm{s}^{-1} \mathrm{~K}^{-1}$

$R \quad$ - polumjer izoliranog vodiča, $\mathrm{m}$

- cable radius, $\mathrm{m}$

$R_{\mathrm{g}} \quad$ - opća plinska konstanta, $R_{\mathrm{g}}=8,314 \mathrm{~J} \mathrm{~mol}^{-1} \mathrm{~K}^{-1}$

- gas constant

$r$ - prostorna koordinata u radijalnom smjeru, $\mathrm{m}$

- space coordinate in radial direction, $\mathrm{m}$

$T$ - temperatura, $\mathrm{K}$

- temperature, $\mathrm{K}$

$t \quad$ - vrijeme reakcije, $\mathrm{s}$

- time, s

$u \quad$ - linearna brzina, brzina linije, $\mathrm{m} \mathrm{s}^{-1}$

- cable linear velocity, $\mathrm{m} \mathrm{s}^{-1}$

z $\quad$ - prostorna koordinata $\mathrm{u}$ aksijalnom smjeru, $\mathrm{m}$

- space coordinate in axial direction, $m$

$\delta \quad$ - Stefan-Bolzmannova konstanta, $\delta=5,67 \cdot 10^{-8} \mathrm{~W} \mathrm{~m}^{-2} \mathrm{~K}^{-4}$

- Stefan-Boltzmann constant

$\varepsilon \quad-$ emisivnost materijala

- emissivity

$\theta \quad$ - bezdimenzijska temperatura

- dimensionless temperature

$\lambda \quad-$ koeficijent toplinske provodnosti, $\mathrm{J} \mathrm{m}^{-1} \mathrm{~s}^{-1} \mathrm{~K}^{-1}$

- heat conductivity, $\mathrm{J} \mathrm{m}^{-1} \mathrm{~s}^{-1} \mathrm{~K}^{-1}$

$\rho \quad-$ gustoća, $\mathrm{kg} \mathrm{m}^{-3}$

- density, $\mathrm{kg} \mathrm{m}^{-3}$ 


\section{Literatura \\ References}

1. IEC, International standard for Extruded solid dielectric insulated power cables for rated voltages from $1 \mathrm{kV}$ up to $30 \mathrm{kV}, \mathrm{CEI}, 1-79,1994$.

2. "Katalog tvrtke Elka d. o. o.", 2012.

3. G. Matey, C. Richardson, Improved XLPE for MV cable performance, Wire industry (1990) 35-40.

4. V. Kosar, Z. Gomzi, K. Šintić, Modelling and simulation of the continuous power cable processing, Chem. Eng. Process. Process Intensif. 46 (2) (2007) 83-88, doi: https://doi.org/10.1016/j.cep.2006.05.001.

5. V. Kosar, Z. Gomzi, Modeling of the power cable production line, Thermochim. Acta 457 (1-2) (2007) 7082, doi: https://doi.org/10.1016/j.tca.2007.02.020.

6. Y. D. Schkalle, Steam vulcanized high-voltage cables, Wireworld (1988) 28-33.

7. B. Likozar, M. Kranjc, Kinetic modeling of the peroxide cross-linking of polymers: From a theoretical model framework to its application for a complex polymer system, Chem. Eng. Process. Process Intensif. 50 (2) (2011) 200-210, doi: https://doi.org/10.1016/j. cep.2010.12.007.

8. G. Milani, F. Milani, Numerical assessment of rubber insulated electric cables plants efficiency using nitrogen and steam water as curing agents, u M. S. Obaidat, J. Kacprzyk, T. Ören, J. Filipe (ur.), Simulation and Modeling Methodologies, Technologies and Applications, Advances in Intelligent Systems and Computing, 2016., str. 1-20, doi: https://doi.org/10.1007/978-3319-31295-8 1.

9. G. Milani, F. Milani, Combined numerical, finite element and experimental optimization approach in the production process of medium voltage, rubber-insulated electric cables vulcanized with steamwater. Part 2: Numerical simulations and inverse analyses, Rubber Chem. Technol. 88 (4) (2015) 527-546, doi: https:// doi.org/10.5254/rct.15.85939.

10. G. Milani, A. Galanti, C. Cardelli, F. Milani, A. Cardelli, Combined numerical, finite element and experimental optimization approach in the production process of medium voltage, rubber-insulated electric cables vulcanized with steamwater. Part 1: DSC and rheometer experimental results, Rubber Chem. Technol. 88 (3) (2015) 482-501, doi: https://doi.org/10.5254/ rct.15.85971.

\title{
SUMMARY
}

\section{Crosslinking Modelling of the Power Cable Insulation Processing \\ Vanja Kosar,a* Zlatko Kraljević, ${ }^{\mathrm{b}}$ and Marina Radovića}

\begin{abstract}
During the manufacture of power cables insulated with crosslinkable polyethylene, the hot polymer is applied to the conductor by extrusion, below temperatures of rapid crosslinking. The coated cable passes into a high-pressure tube (filled with nitrogen under pressure of $10 \mathrm{bar}$ ) in order to heat up the insulation to temperatures at which the crosslinking agent is highly active. This is the continuous vulcanization (CV) tube. Changes in process variables associated with the CV tube can cause changes in the physical properties, aging characteristics, and especially heat resistance of the cable insulation. Performance of insulating compounds in this area of the crosslinking process can determine maximum output rates of a power cable manufacturing facility.

Most power cable manufacturers have determined the optimum operating conditions for their cure tubes through practical experiments. However, the introduction of new resins or different cable constructions often leads to inefficient operation or erroneous evaluation because of the inability to predict performance in the tube. In addition, when using other insulation materials, it is necessary to conduct a series of independent experiments for their characterization. This can often lead to overdesign or underdesign of new equipment. With this point in mind, a mathematical model of the continuous vulcanization (CV) process, which provides a simulation of the process has been developed.
\end{abstract}

\section{Keywords}

Crosslinking, vulcanization tube, XLPE, insulated conductor, mathematical model, simulation

${ }^{a}$ Faculty of Chemical Engineering and

Technology, University of Zagreb

Marulićev trg 19

10000 Zagreb, Croatia

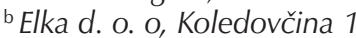

10000 Zagreb, Croatia
Original scientific paper

Received January 4, 2017 Accepted February 22, 2017 